OPEN ACCESS

Edited by:

Mitsuhiro Kawata,

Kyoto Prefectural University of

Medicine, Japan

Reviewed by:

Tatsushi Onaka,

Jichi Medical University, Japan

Gábor B. Makara,

Hungarian Academy of Sciences,

Hungary

*Correspondence: H. Elliott Albers biohea@gsu.edu

Specialty section: This article was submitted to Neuroendocrine Science, a section of the journal

Frontiers in Endocrinology

Received: 16 August 2017

Accepted: 23 October 2017

Published: 14 November 2017

Citation:

Terranova Jl, Ferris CF and Albers HE (2017) Sex Differences in

the Regulation of Offensive Aggression and Dominance by Arginine-Vasopressin.

Front. Endocrinol. 8:308. doi: 10.3389/fendo.2017.00308

\section{Sex Differences in the Regulation of Offensive Aggression and Dominance by Arginine-Vasopressin}

\author{
Joseph I. Terranova ${ }^{1}$, Craig F. Ferris ${ }^{2}$ and H. Elliott Albers ${ }^{1 *}$ \\ ${ }_{1}^{1}$ Center for Behavioral Neuroscience, Neuroscience Institute, Georgia State University, Atlanta, GA, United States, \\ ${ }^{2}$ Department of Psychology, Center for Translational Neurolmaging, Northeastern University, Boston, MA, United States
}

Arginine-vasopressin (AVP) plays a critical role in the regulation of offensive aggression and social status in mammals. AVP is found in an extensive neural network in the brain. Here, we discuss the role of AVP in the regulation of aggression in the limbic system with an emphasis on the critical role of hypothalamic AVP in the control of aggression. In males, activation of AVP V1a receptors (V1aRs) in the hypothalamus stimulates offensive aggression, while in females activation of V1aRs inhibits aggression. Serotonin (5-HT) also acts within the hypothalamus to modulate the effects of AVP on aggression in a sex-dependent manner. Activation of $5-\mathrm{HT} 1$ a receptors (5-HT1aRs) inhibits aggression in males and stimulates aggression in females. There are also striking sex differences in the mechanisms underlying the acquisition of dominance. In males, the acquisition of dominance is associated with the activation of AVP-containing neurons in the hypothalamus. By contrast, in females, the acquisition of dominance is associated with the activation of 5-HT-containing neurons in the dorsal raphe. AVP and 5-HT also play critical roles in the regulation of a form of social communication that is important for the maintenance of dominance relationships. In both male and female hamsters, AVP acts via V1aRs in the hypothalamus, as well as in other limbic structures, to communicate social status through the stimulation of a form of scent marking called flank marking. 5-HT acts on 5-HT1aRs as well as other 5-HT receptors within the hypothalamus to inhibit flank marking induced by AVP in both males and females. Interestingly, while AVP and 5-HT influence the expression of aggression in opposite ways in males and females, there are no sex differences in the effects of AVP and 5-HT on the expression of social communication. Given the profound sex differences in the incidence of many psychiatric disorders and the increasing evidence for a relationship between aggressiveness/dominance and the susceptibility to these disorders, understanding the neural regulation of aggression and social status will have significant import for translational studies.

Keywords: gender differences, agonistic behavior, social status, social communication, oxytocin, serotonin, V1a receptors, $\mathbf{V} 1 \mathrm{~b}$ receptors

\section{AGGRESSION}

Aggression is a complex phenomenon that has many different forms and adaptive functions (1-4). Aggression has been classified in a variety of ways, but the three forms of aggression that have been studied most extensively and that may be most closely linked with reproductive success are offensive aggression, defensive aggression, and parental aggression (the most frequently studied form of parental aggression is maternal aggression). Offensive aggression has been defined as aggression involving 
response to challenge over important resources; defensive aggression as attack in defense of an individual's own integrity; and maternal aggression as aggression aimed at intruders threatening the offspring of a lactating female. As noted by Blanchard et al. (5), "the distinction between offensive and defensive aggression is based on a number of aspects of behavior, including antecedent conditions, organismic variables, attack topography (target of attack on the opponent's body), and typical outcomes." The ethograms for offensive and defensive aggression are unique (6). Maternal aggression appears to include elements of both offensive and defensive aggression and probably represents a mixed category (7). Therefore, based on these criteria, the current consensus is that offensive, defensive, and maternal aggression represent different categories of aggression, although similar behaviors can, at times, be observed in all three categories. In this review, we will focus on the role of arginine-vasopressin (AVP) in mammalian offensive aggression and how this role relates to the formation and maintenance of social relationships [for reviews of the role of AVP in maternal aggression see Ref. (7-9)]. When aggression occurs during a social encounter between strangers, both offensive and defensive aggression is observed. Winners and losers are rapidly determined and winners become dominant and losers subordinate. Along with the formation of dominant/subordinate relationships, aggressive behavior declines and other agonistic behaviors that serve to reinforce social status occur in increasing frequency (e.g., social communication). In the second section of this review, the role of AVP in the formation and maintenance of social status will be discussed.

\section{AVP and the Neural Control of Offensive Aggression in Males}

Historically, AVP has been well known for its many physiological actions in the periphery, including water reabsorption and cardiovascular homeostasis (10). More recently, however, AVP has been identified as a critical neurochemical signal in the neural circuitry regulating offensive aggression. Neuroanatomical studies have demonstrated that in addition to the well-known AVP-containing hypothalamic projections to the neurohypophysis, there is an extensive neural network of AVP-containing projections throughout the brain (11-13) (Figure 1). For example, in Syrian hamsters, AVP neurons originating from hypothalamic nuclei, such as the medial supraoptic nucleus $(\mathrm{mSON})$, nucleus circularis (NC), and paraventricular nucleus (PVN), project to many brain regions thought to be involved in regulating social behavior. There is increasing evidence that this AVP circuitry is engaged during social encounters. During agonistic encounters, enhanced activation of AVP-containing neurons in the mSON and NC is observed in male hamsters compared to controls (13). Cross-fostering male California mice with the less aggressive and less territorial white-footed mouse reduces adult aggression and the amount of AVP- immunoreactivity (ir) in the $\mathrm{mSON}$ and the bed nucleus of the stria terminalis (BNST) (14). After an agonistic encounter between female pigs the expression of AVP mRNA is enhanced in the medial amygdala, septum, and BNST of aggressive compared to non-aggressive individuals (15).

The first evidence that AVP is involved in the control of aggression came from the finding that injection of an antagonist of the V1a AVP receptor (V1aR) into the anterior hypothalamus $(\mathrm{AH})$ of male hamsters inhibits aggression $(25,26)$. Subsequent studies in hamsters and voles have found that AVP administered within the AH can stimulate high levels of aggression (27-30). Interestingly, however, the ability of AVP to stimulate aggression within the $\mathrm{AH}$ appears to depend on an upregulation in the number of V1aRs in the AH. This upregulation appears to occur as the result of specific types of social experience. For example, AVP is effective in increasing aggression following its injection into the $\mathrm{AH}$ in male hamsters that had previously been trained to fight but not in hamsters housed in stable social groups $(27,31)$. Socially isolated male hamsters also display higher

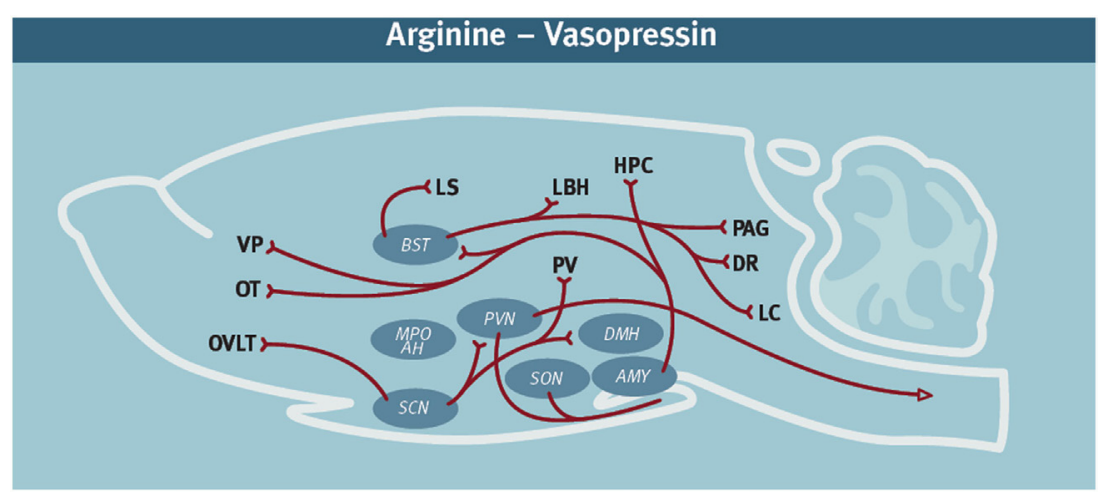

FIGURE 1 | Diagram of the arginine-vasopressin (AVP)-containing neural network in rodents. It is noteworthy that AVP immunoreactivity can vary by species, sex, age, and social experience $(16,17)$. These diagrams represent a compilation of the major AVP projections from several rodent species. In addition to the cell bodies indicated in the diagram, there are also accessory nuclei that likely also play an important role. AVP network (11, 18-23). Abbreviations: AMY, amygdala; DR, dorsal raphe; HPC, hippocampus; LS, lateral septum; LC, locus coeruleus; MPO AH, medial preoptic area-anterior hypothalamus; OT, olfactory tubercle; OVLT, organum vasculosum laminae terminalis; PVN, paraventricular nucleus; PAG, periaqueductal gray; PV, periventricular nucleus hypothalamus; SCN, suprachiasmatic nucleus; SON, supraoptic nucleus; VP, [figure modified from Ref. (24) with permission]. 
levels of aggression and greater numbers of V1aRs in the $\mathrm{AH}$ than socially housed males $(32,33)$.

The upregulation of V1aRs in the AH also appears to be important in AVP regulation of male aggression in voles. Following pair bonding, male prairie voles engage in high levels of aggression and have significantly more V1aRs in the $\mathrm{AH}$ than sexually naïve voles $(29,34)$. There is also significantly more aggression and higher levels of AVP released in the AH in pair bonded males exposed to novel females than in males exposed to their female partners. It has been suggested that AVP is necessary for the transition to increased aggressiveness following pair bonding but not for the expression of aggressive behavior (34). In support of this idea is the finding that V1aR antagonists block the induction of partner preference but not the expression of aggression displayed by breeder male voles with established selective aggression (34). On the other hand, induction of large numbers of V1aRs in the $\mathrm{AH}$ by viral vector-mediated gene transfer significantly increases aggression in non-pair bonded males (29). In summary, social experience can modulate the number of V1aRs in the $\mathrm{AH}$ and the number of $\mathrm{V} 1 \mathrm{aRs}$ in the $\mathrm{AH}$ can regulate the amount of male offensive aggression. Nevertheless, the precise role of V1aRs in regulating aggression remains to be determined and it is important to note that high levels of aggression can occur in the absence of $\mathrm{V} 1 \mathrm{aR}$ activation at least in males with prior aggressive experience.

Further support for the role of AVP and V1aRs in the control of aggression comes from studies examining how drugs of abuse can stimulate aggression. Anabolic steroids (AAS) administered to adolescent male hamsters produce high levels of aggression that is inhibited by a V1aR antagonist injected into the $\mathrm{AH}$ (35). AAS also increases AVP fiber density and content within the $\mathrm{AH}$ without altering V1aR binding (36-38). Conversely, after 18 days of withdrawal from AAS, there is a reduction in both aggressive behavior and AVP fiber density in AAS-treated male hamsters (39). Chronic, low-dose cocaine treatment during adolescence increases adulthood aggression and electrically stimulated AVP release in the $\mathrm{AH}$ of male hamsters $(40,41)$. In male prairie voles, administration of amphetamine increases aggression and increases $\mathrm{V} 1 \mathrm{aR}$ binding in the $\mathrm{AH}$ (29). In summary, drugs of abuse can act within the AH to alter aggression by influencing the amount of AVP innervation and/or by altering the number of VlaRs.

Another hypothalamic region where AVP plays an important role in male aggression is the ventrolateral hypothalamus (VLH). Injection of AVP into the VLH increases aggression in gonadally intact male hamsters and castrated males given testosterone but not in castrated males without testosterone replacement (42). The effects of testosterone on AVP-stimulated aggression are likely mediated by the effects of testosterone on V1aR number in the VLH. Castration reduces VlaR binding in the VLH and pre-castration levels of $\mathrm{V} 1 \mathrm{aR}$ binding can be restored by the administration of testosterone (43-45).

There is also evidence for a relationship between aggression and AVP in other regions of the limbic system. In male California mice, aggression is positively correlated with the number of AVP-ir neurons in the posteromedial BNST (46). In the septum, a negative correlation between AVP fiber density and male aggression has been observed in strains of rats and mice bred for varying levels of aggression $(47,48)$. In other studies, employing rats selected for low or high anxiety, the release of AVP in the septum is considerably lower in the much more aggressive low anxiety rats than in the less aggressive, high anxiety rats. Interestingly, however, injection of AVP or a V1aR antagonist into the septum does not alter the expression of aggression in the low aggressive or high aggressive rats (49). Thus, although relationships between aggression and AVP-ir and release exist in the LS, there is no direct evidence that AVP acts in the septum to modulate aggression.

Gene targeting approaches have also been used to study the role of AVP receptors in male aggression. Surprisingly complete knockout of V1aRs has no effect on aggression in male mice and produces only a slight deficit in olfaction (50). By contrast, knockout of AVP V1b receptors (V1bR) significantly reduces aggression $(51,52)$. Further the reduction in offensive aggression in $\mathrm{V} 1 \mathrm{~b}$ knockout mice is due to deficits in social motivation and not in deficits in olfactory function $(53,54)$. Interestingly, knockout of the V1bR gene produces deficits specific to forms of aggression directed toward a conspecific (55). Further support for a role of V1bRs in aggression come from pharmacological studies where peripheral administration of a V1bR antagonist reduced aggression in male hamsters (56). V1bRs in the hippocampus likely play a prominent role regulating aggression. When $\mathrm{V} 1 \mathrm{bR}$ function is restored in the CA2 region of the hippocampus in male knockout mice by lentiviral delivery of the V1bR gene, offensive aggression is partially restored (57). The ability of mice to express aggression in the absence of V1aRs is surprising given the considerable pharmacological data in other species indicating the importance of V1aRs in male aggression. The simplest explanation for the continued aggressiveness of these knockout mice might be a developmental compensation for the life-long loss of V1aRs. Perhaps the V1bR acts as such a compensatory mechanism that preserves aggressive behavior in the $\mathrm{V} 1 \mathrm{aR}$ knockout mice.

\section{AVP and the Neural Control of Offensive Aggression in Females}

Little is known about the neurobiology of offensive aggression in females. The emphasis of competitive behaviors, such as offensive aggression in sexual selection in males, has resulted in little attention being paid to the neural control of offensive aggression in females (58). It is clear, however, that females as well as males compete for resources and mates to achieve reproductive benefits and that female competition has a significant role in evolution in mammals (59-61). Females compete for resources such as food, nest sites, and protection using a number of different strategies, including intergroup aggression, dominance relationships, and territoriality. As such, there are similarities in many of the competitive behaviors expressed by males and females (e.g., offensive aggression). Although many of the competitive behaviors displayed by males and females are similar, the neural mechanisms controlling them may be fundamentally different. Evolutionary biology would suggest that the social strategies used by females and males evolved in response to very different selective pressures. As a result, it seems likely that some of these behavioral similarities arose as the result of convergent evolution in the neural mechanisms 
controlling social behavior. Indeed, the likelihood that there are sex differences in the neural mechanisms regulating aggression highlight the importance of a better understanding of how these mechanisms function in males and females. Given the substantial sex differences in the incidence of many psychiatric disorders, understanding the sex differences in the neural mechanisms regulating social behavior has the potential for substantial translational significance (62).

Another reason for the absence of data on the neurobiology of offensive aggression in females is the choice of species used to study the physiological mechanisms controlling aggression. Studies of the physiology of aggression have been conducted primarily in laboratory rats and mice $(5,7)$. Because laboratory rats and mice rarely display female offensive aggression, few studies on the physiological regulation of these critically important forms of aggression have been conducted $(63,64)$. Another laboratory species, Syrian hamsters, provide an outstanding model with which to study female competitive behavior. Female hamsters, like many female primates, display a number of different competitive strategies such as the expression of spontaneous offensive aggression, the rapid formation of hierarchical dominance relationships, and the ability to inhibit the reproductive capacity of other females (65-67).

Studies in hamsters provide the first evidence that there are fundamental sex differences in the neural circuitry controlling offensive aggression and that some of these sex differences involve AVP. AVP in the AH has opposite effects on the expression of aggression in males and females. Injection of AVP into the AH of female hamsters reduces aggression, whereas injection of a $\mathrm{V} 1 \mathrm{aR}$ antagonist in female hamsters increases aggression $(68,69)$. While social isolation increases aggression in female hamsters, as it does in male hamsters, there is no increase in V1aR density in female hamsters as there is in males (33).

There are also some interesting sex differences in the developmental effects of AVP on adult aggression. AVP administered during the early postnatal period influences the expression of adult aggression in a sex-dependent manner $(70,71)$. Male but not female prairie voles exhibit significantly higher levels of aggression as adults when administered AVP peripherally during the early postnatal period. Taken together, the existing data indicate that AVP can play a critical, but opposite role in the regulation of aggression in males and females.

There is only a limited amount of data on the role of AVP in aggression in primates. In chimpanzees, polymorphisms of the V1aR gene are associated with enhanced or reduced aggressive behaviors (72). In humans, AVP cerebrospinal fluid levels positively correlate with a life history of aggression in individuals who meet DSM-IV criteria for personality disorder (73). Other studies in humans while not directly addressing the effects of AVP on aggression have identified some striking differences in the effect of AVP on social cognition. Intranasal administration of AVP in humans has sex-dependent effects on the social valence of stimuli (74). In women, AVP enhanced the perception of friendliness in the faces of unfamiliar women and stimulated affiliative facial motor patterns. In men, AVP reduced the perception of friendliness in the faces of unfamiliar men and stimulated agonistic facial motor patterns.

\section{AVP Interactions with Other Neurochemical Signals in the Control of Aggression}

Arginine-vasopressin interacts with several neurochemical signals to regulate offensive aggression. In males, serotonin (5-HT) has potent inhibitory effects on the expression of aggression in species ranging from fish to primates and at least some of these effects of 5-HT are mediated by its interactions with $\operatorname{AVP}(30,75)$. One site where AVP and 5-HT likely interact to regulate aggression is the $\mathrm{AH}$. The $\mathrm{AH}$ receives $\mathrm{AVP}$-containing projections from the $\mathrm{mSON}$ and $\mathrm{NC}$ as well as 5-HT-containing projections from the raphe $(13,76)$. Co-infusion of AVP and the 5-HT1a receptor (5-HTlaR) agonist 8-OH-DPAT into the AH of male hamsters produces higher levels of aggression than 8-OH-DPAT alone and lower levels of aggression than AVP $(69,77)$. Systemic administration of the selective serotonin reuptake inhibitor, fluoxetine, decreases aggression in male hamsters (27) and pre-treatment with fluoxetine blocks AVP-induced aggression in both the AH and $\operatorname{VLH}(42,77,78)$. Chronic administration of fluoxetine during male adolescence increases both adulthood aggression and AVP fiber innervation in the AH $(79,80)$.

Surprisingly, although the effects of 5-HT have been investigated in hundreds of studies in males, not until recently have the effects of 5-HT been examined in females $(81,82)$. By contrast, to the striking inhibitory effects of 5-HT on aggression in males, injection of 8-OH-DPAT into the AH produces a dose-dependent increase in aggression in females. Co-infusion of AVP and 8-OH-DPAT into the AH of female hamsters produces lower levels of aggression than 8-OH-DPAT alone and higher levels of aggression than AVP $(69,77)$. Taken together, these studies indicate that AVP and 5-HT act in opposite ways within the $\mathrm{AH}$ to regulate offensive aggression in males and females.

Oxytocin (OT) is very similar in structure to AVP sharing seven of nine amino acid sequences $(83,84)$. In addition, OT and AVP receptors are very similar in structure and can respond in a relatively unselective manner to both neuropeptides (24). Indeed, OT can have effects on aggression similar to those of AVP. Like AVP, OT injected into the AH reduces aggression in a dose-dependent manner in female hamsters (85). Injection of an $\mathrm{OT}$ antagonist into the $\mathrm{AH}$ increases aggression in female hamsters (85). Total OT knockout male and female mice have higher levels of aggression than controls as do total male OT receptor (OTR) knockouts (86-88). There is increasing evidence that OT and AVP can influence a number of different social behaviors by acting on each other's receptors. OT or AVP induce social communication behavior by activating V1aRs but not OTRs, while OT or AVP can enhance social recognition and social reward by activating OTRs but not V1aRs (24,89-92). While both OT and AVP can influence the expression of aggression the roles of OT and AVP receptors in mediating these effects remains to be fully understood.

Glutamate is also capable of interacting with AVP in the neural control of aggression. In a model of heightened male aggression in which male hamsters are chronically exposed to AAS during adolescence, glutamate receptor subunit type 1 density 
is increased in the VLH and vesicular glutamate transporter 2 density is increased in the AH, two brain regions where AVP acts to control aggression $(93,94)$. Interestingly, AVP can induce the release of glutamate from astrocytes through binding of both V1aRs and V1bRs (95). AVP-induced release of glutamate provides a potential mechanism through which offensive aggression could be facilitated within the AH and VLH.

\section{SOCIAL STATUS}

For most mammalian and non-mammalian species, the formation and maintenance of dominance relationships rely on agonistic behaviors, particularly aggression and social communication. Although aggression has been commonly characterized as a negative social interaction, aggression plays a very constructive role in the formation of these important social relationships. In nearly all mammals, dominance relationships represent social relationships that have many adaptive functions (e.g., resource distribution) ultimately resulting in a reduction of social conflict (96). Most dominance relationships are determined rapidly by aggression but are primarily maintained by social communication (e.g., scent marking, vocalization, non-contact aggression or harassment, etc.) thereby reducing the dangers of continual, intense conflict (97). Success in maintaining these relationships depends on social skills that are also hallmarks of psychiatric health, such as effective social communication. If, for example, social communication is dysfunctional, then the social interactions become maladaptive, resulting in continuously high levels of social conflict (98). Importantly, dominance relationships have different consequences for the winners and the losers. Winning is rewarding $(99,100)$ and losing is stressful $(101)$, particularly if subordinate status is imposed continually over time $(102,103)$. Indeed, losing is known to be a potent and ethologically relevant stressor and has become a leading model for investigation of the neural circuits and behavioral phenotypes (104) that are activated by social stress (105-107) and that have been widely shown to be useful models of stress-related mood and anxiety disorders (108-110).

\section{AVP and the Neural Control of Social Status in Males}

Social relationships among animals commonly take the form of hierarchical dominance relationships. Although the focus of this review is on the role of AVP in social status in mammals, there is considerable evidence that the non-mammalian homolog of AVP, arginine-vasotocin plays an important role in dominance relationships in birds, reptiles, amphibians, and fish [for reviews, see Ref. (111-115)]. Given its role in aggression, it is not surprising that AVP is also involved in the acquisition and maintenance of dominance relationships. In male hamsters, AVP-ir neurons in the mSON and NC display significantly higher levels of activation (as indicated by increased AVP-ir/fos-ir) in winners (i.e., dominants) than in losers (i.e., subordinates) or controls after a single agonistic encounter (69) (Figure 2). Differences in social status are associated with differences in AVP-ir and V1aR binding in the hypothalamus. Subordinate male hamsters in stable dominance relationships have significantly fewer AVP-ir neurons in the NC compared to dominant and control males (116) and dominant male hamsters have significantly more V1aR binding than subordinate or control hamsters in the hypothalamus (117). V1bR knockout male mice can establish dominance hierarchies suggesting that V1bRs may not be essential for the formation of these relationships. Non-dominant V1bR knockout mice do, however, engage in less offensive aggression than wild-type controls (118).

Social status is associated with different amounts of AVP-ir in several hypothalamic regions. In mandarin voles, dominant males have significantly more AVP-ir in the PVN, SON, LH, and $\mathrm{AH}$ than subordinates (119). Interestingly, no differences were observed in OT-ir between dominant and subordinate male voles in any of these brain regions except the PVN where OT-ir was lower in dominant than in subordinate males. By contrast, in male mice subordination seems to be associated with higher levels of AVP-ir in the PVN. In male California mice, a single social defeat significantly increases the activation of AVP neurons (i.e., AVP-ir/ fos-ir) in both the PVN and SON (46). In addition, more than 10 weeks after social defeat AVP mRNA and AVP-ir were significantly reduced in the PVN. In an inbred strain of mice, chronic defeat increases AVP mRNA expression in the PVN of males (120). Adolescent male hamsters that are chronically defeated are more aggressive in adulthood toward smaller, weaker hamsters and less aggressive toward larger, stronger hamsters (121). Social subjugation also results in a 50\% reduction in AVP-ir fiber density in the region of the $\mathrm{AH}$ involved in regulating aggression (121).

Several studies have also examined the effects of the porcine form of vasopressin, lysine-vasopressin (LVP), on dominant and subordinate behavior. LVP differs from AVP in that lysine is substituted for arginine in the eighth amino acid position. In male mice, administration of LVP increases submissive behavior when given prior to social defeat, immediately after social defeat, or immediately prior to a social interaction the day following social defeat $(122,123)$. By contrast, LVP administration prior to social defeat has no effect on dominance behavior (122-124). Interestingly, LVP binds to OTRs with a higher affinity than to AVP receptors suggesting the possibility that the ability of LVP to enhance submissive and not dominance behavior is mediated by OTRs (125).

A key element in the maintenance of dominance relationships is effective social communication $(3,97,98)$. In hamsters, an important form of social communication is a type of scent marking called flank marking (126). Flank marking is used to communicate a variety of socially important information including social status $(98,126,127)$. AVP plays a critical role in regulating flank marking by its actions within the hypothalamus as well as several other structures including the lateral septum and periaqueductal gray (128-132). Indeed, injection of AVP into the hypothalamus induces high levels of flank marking and injection of a selective V1aR antagonist blocks the expression flank marking (90, 133-136). After an initial agonistic encounter between two hamsters where dominance is defined by the winner of aggressive interactions, the levels of aggression rapidly decline and the expression of flank marking increases (98). Interestingly, flank marking increases in both the dominant and subordinate hamster, although the amount of flank marking 


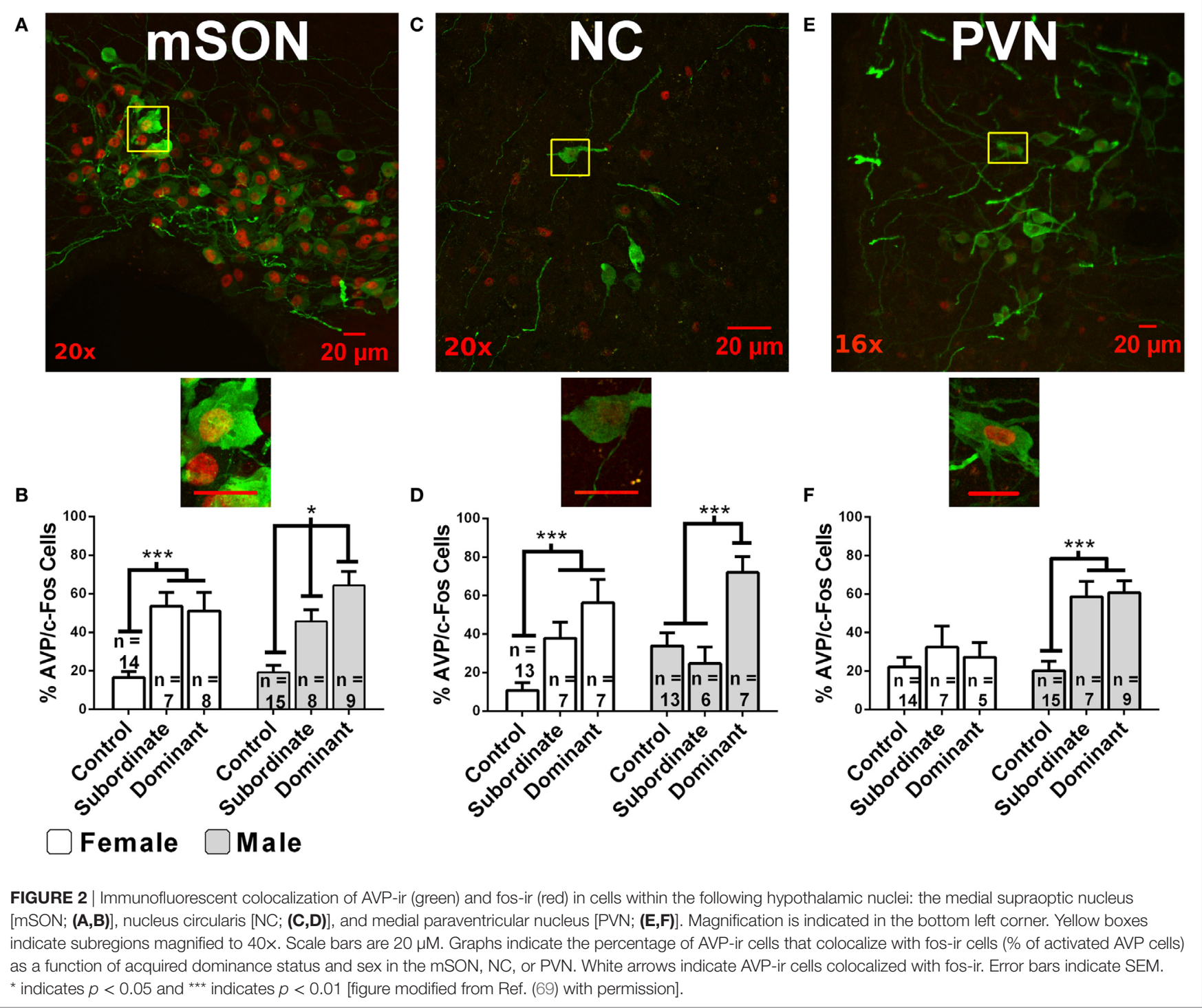

is substantially higher in the dominant. When the dominant hamster's flank marking is inhibited by hypothalamic injection of a V1aR antagonist the subordinate increases its flank marking (137). Interestingly, inhibition of flank marking in dominant hamsters by the injection of a V1aR antagonist while simultaneously stimulating flank marking in the subordinate by the injection of AVP for several consecutive days does not produce a reversal of social status. On the day immediately after the injections are terminated, the initially dominant hamster again flank marks significantly more than its subordinate partner (Figure 3). Thus, while flank marking communicates dominance status, it does not determine dominance status.

\section{AVP and the Neural Control of Social Status in Females}

Comparatively little is known about the role of AVP in the neural mechanisms regulating dominance relationships in females. One approach has been to examine the relationship between the numbers of AVP-ir neurons and social status. In mandarin voles, dominant females have significantly more AVP-ir cells in the AH and LH than subordinates (119). No differences were found in the number of AVP-ir cells in either the PVN or SON. Significant sex differences in the number of AVP-ir cells were also observed. Dominant females have significantly fewer AVP-ir cells in the $\mathrm{PVN}, \mathrm{SON}, \mathrm{AH}$, and $\mathrm{LH}$ than dominant males and subordinate females have significantly lower levels of AVP-ir than subordinate males. No differences were observed in OT-ir between dominant and subordinate females in any of the brain regions examined.

Another approach has been to examine the relationship between social status and the activation of AVP-containing neurons. Following social defeat, female California mice, like males, have significantly more activated AVP neurons (i.e., AVP-ir/fos-ir) in both the SON and PVN (46). While the acute of effects of defeat are similar in females and males the long term effects of defeat on AVP neurons is stronger in males than in females. In hamsters, neuronal activation in AVP-containing neurons (i.e., AVP-ir/fos-ir) 


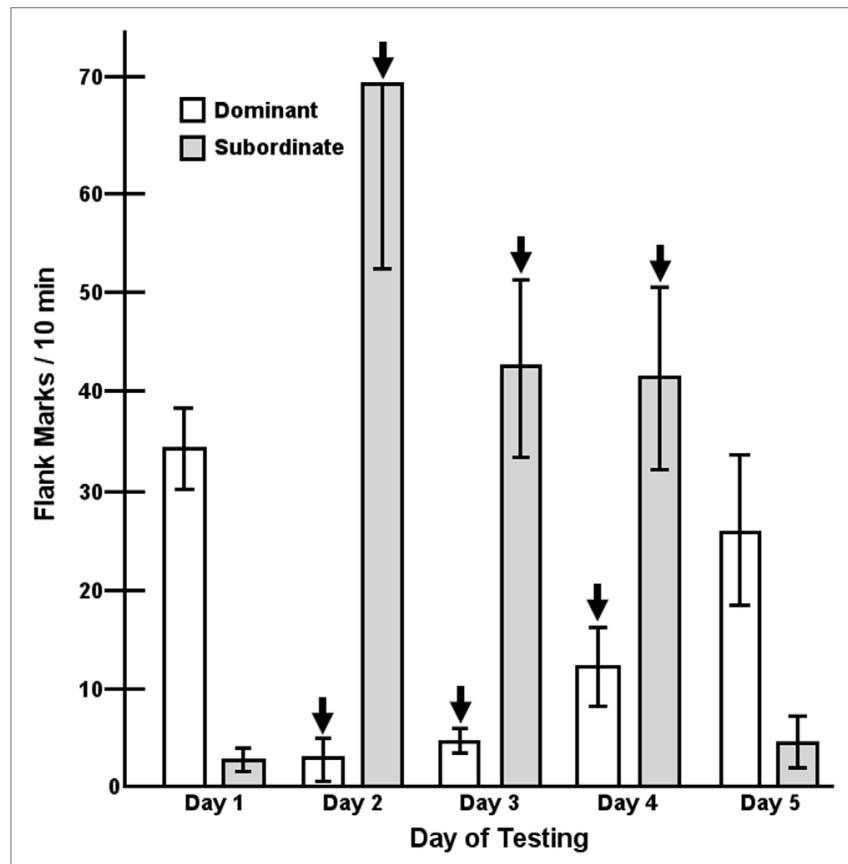

FIGURE 3 | Flank marking in pairs $(n=5)$ of dominant/subordinate male hamsters in response to the microinjection of dPTyr(Me)AVP [V1a receptor (V1aR) antagonist] and arginine-vasopressin into dominant and subordinate members, respectively, over three consecutive days (arrows, days 2-4). Each bar represents the mean \pm SEM of the number of flank marks made in a 10-min test over five consecutive days. A two-way analysis of variance resulted in a significant treatments by trials interaction, $F(4,32)=24.04$, $p<0.001$ [figure modified from Ref. (98) with permission].

in the $\mathrm{NC}$ and $\mathrm{mSON}$ is higher in both male and female hamsters following an agonistic encounter than in controls (Figure 3). In females, however, similar levels of activation are seen in dominant and subordinate hamsters, while dominant male hamsters display significantly higher levels of activation as compared to subordinate males (69). Thus, there is a substantial sex difference in the relationship between social status and the activation of AVP-containing neurons within the hypothalamus.

Arginine-vasopressin plays an important role in the communication of social status in female hamsters as it does in males (3). Perhaps surprisingly given the opposite effects of AVP on aggression in the AH in males and females, AVP induces flank marking at high levels in both males and females (133). Indeed, the dose-response relationship between the hypothalamic injection of AVP and flank marking are almost identical in male and female hamsters (138). It, therefore, seems likely that although V1aRs mediate the effects of AVP on aggression and flank marking there are important differences in the circuitry controlling these behaviors. Whether separate populations of V1aRs in the AH control aggression and flanking marking is not known, there is some evidence to support this possibility. Exposure to short "winter-like" photoperiods significantly reduces, but does not eliminate V1aR binding in the $\mathrm{AH}$ of male hamsters (139). Interestingly, short photoperiod significantly reduces the ability of AVP injected into the AH to increase aggression but has no effect on the ability of AVP to induce flank marking $(28,139)$. As such, there may be a short photoperiod sensitive subpopulation of V1aRs in the $\mathrm{AH}$ that mediate aggression and a short photoperiod in-sensitive subpopulation of $\mathrm{V} 1 \mathrm{aRs}$ in the $\mathrm{AH}$ that mediate flank marking.

\section{AVP Interactions with Other Neurochemical Signals in the Control of Dominance}

Several neurochemical signals can interact with AVP to modulate the communication of social status. In female hamsters, injection of norepinephrine significantly reduces AVP-induced flank marking by its actions in the $\mathrm{AH}$ (140). In male hamsters, injection of galanin into the AH significantly reduces AVP-induced flank marking $(141,142)$. Glutamate receptors within the $\mathrm{AH}$ appear to be necessary for the induction of flank marking by AVP at least in male hamsters (143). Co-administration of the glutamate receptor antagonists AP-5 or GAMS significantly inhibits the expression of AVP-induced flank marking. Further support for the hypothesis that glutamate has a critical role in AVP-induced flank marking comes from evidence that AVP can induce glutamate release from astrocytes (95).

There is considerable evidence that 5-HT can modulate AVPinduced flank marking. As discussed earlier, both AVP- and 5 -HT-containing projections terminate in the $\mathrm{AH}$ so the $\mathrm{AH}$ is a likely site for AVP-5-HT interactions $(13,76)$. When 5-HT or 5-HT agonists are combined with AVP and injected into the $\mathrm{AH}$, the ability of AVP to stimulate flank marking is substantially reduced in both males and females $(142,144,145)$. The 5-HT receptor subtypes mediating the effects of 5-HT on flank marking in the $\mathrm{AH}$ are not fully defined but there is evidence for the potential involvement of 5-HT1a, 5-HT1b, 5-HT7, and 5-HT4 receptors (146). Systemic administration of fluoxetine can also reduce flank marking produced by injection of AVP into the $\mathrm{AH}$ or VLH so 5-HT could be acting a multiple brain sites to inhibit flank marking $(144,147)$.

The raphe likely plays an important role in mediating how AVP and 5-HT interact to regulate social status given its substantial projections to the AH. Indeed, in female hamsters, 5-HT-ir neurons in the dorsal raphe (DRN) display significantly higher levels of activation (as indicated by increased 5-HT-ir/fos-ir) in winners (i.e., dominant) than in losers (i.e., subordinates) or controls after a single agonistic encounter (69). By contrast, a similar relationship between social status and the activation of 5-HT neurons in the DRN is not seen in males. Despite these major sex differences, there is also a more nuanced relationship between the activation of DRN neurons and social status in males and females. Subordinate males, but not females, display more activation of 5-HT neurons in the ventral subregion of the anterior DRN than dominant or control males and dominance status alters the activation of 5-HT neurons in the dorsal subregion of the anterior DRN in both males and females (148).

There is additional support for a relationship between 5-HT and social status in males. 5-HT1aR mRNA is higher in the DRN of dominant male hamsters in established dominance relationships compared to subordinates (148). Injection of a 5-HT1aR agonist into the DRN of male hamsters, either prior to social defeat or prior to testing for conditioned defeat, reduces submissive and 
defensive behaviors and infusion of a 5-HT1aR antagonist into the DRN increases submissive and defensive behaviors (149). Systemic injection of a 5-HT2a receptor agonist in male hamsters after social defeat and prior to testing for conditioned defeat decreases submissive behavior toward a non-aggressive stimulus animal (150). Taken together, the DRN is involved in regulating social status in both males and females, although there are major sex differences in the activation of 5-HT neurons during the formation of dominance relationships.

\section{SUMMARY AND CONCLUSIONS}

Arginine-vasopressin plays an important role in the establishment of dominance relationships via its effects on aggression and in the maintenance of dominance relationships by its effects on social communication. Although much remains to be learned about the neural circuitry controlling aggression and social status, the hypothalamus is a key site for the actions of AVP. V1aRs in the hypothalamus appear to be critical for the modulation of aggression and for social communication by AVP. The number of V1aRs in the hypothalamus can be influenced by a variety of factors including social experience and gonadal hormones. In males, AVP-induced aggression appears to require an upregulation of V1aRs. Although the most direct evidence for a role of AVP in modulating aggression has been in the hypothalamus there is a relationship between AVP and aggression in several other limbic structures, including the BNST and septum. Although AVP has a substantial role in regulating male aggression it is not clear if AVP promotes aggression in the same manner in all circumstances. For example, it remains to be determined if AVP drives male aggression directly and/ or whether AVP is necessary for the transition from a nonaggressive state to aggressiveness.

In females, there have been fewer studies examining the role of AVP in regulating aggression. Nevertheless, there appear to be striking sex differences in the hypothalamic effects of AVP on aggression. While AVP stimulates aggression in males, it inhibits aggression in females. Despite the opposite effects of AVP on aggression in males and females the effects of AVP on aggression are mediated by V1aRs in both sexes. There are also sex differences in how V1aRs can be regulated in the hypothalamus. In males, social isolation increases the number of V1aRs in the $\mathrm{AH}$, but in females social isolation does not change the number of V1aRs despite the fact that social isolation increases aggressiveness in both males and females. Interestingly, the hypothalamic effects of 5-HT on aggression complement the effects of AVP. While activation of 5-HTlaRs in the AH inhibits aggression

\section{REFERENCES}

1. DuqueWilckens N, Trainor BC. Behavioral Neuroendocrinology of Female Aggression. Oxford: Oxford Research Encyclopedia of Neuroscience (2017).

2. Moyer KE. The Physiology of Hostility. Oxford, England: Markham (1971).

3. Albers HE, Huhman KL, Meisel RL. Hormonal basis of social conflict and communication. In: Pfaff D, Arnold AP, Etgen A, Fahrbach SE, Rubin RT, editors. Hormones, Brain and Behavior. Amsterdam: Academic Press (2002). p. 393-433. in males, activation of these receptors stimulates aggression in females.

While aggression plays a critical role in the formation of dominance relationships, it becomes less important after the winners and losers have been determined. In most cases, dominance relationships remain comparatively stable over time as communication is used as a "reminder" of an individual's social status. In hamsters AVP has a central role in the social communication of dominance status. Interestingly, although AVP has the opposite effects on aggression in males and females, AVP potently stimulates flank marking in both males and females. These similarities and differences in the effects of AVP on flank marking and aggression are particularly interesting because both appear to be mediated by V1aRs. It seems likely that different subpopulations of V1aRs mediate the effects of AVP on aggression and flank marking even though they are found in overlapping regions of the hypothalamus. It is also interesting that 5-HT has the same inhibitory effects on AVP-stimulated flank marking in males and females.

It has been proposed that aggressiveness, dominance, and active coping strategies may represent traits that result in more resistance to psychiatric disorders $(151,152)$. In addition, a role for the vasopressinergic system in psychiatric disorders is receiving increasing attention (153). Importantly, however, sex differences in the effects of AVP on social behavior and in particular on aggression have received little attention. Given the substantial sex differences in the effects of AVP and 5-HT on aggression and dominance and the dramatic sex differences seen in the incidence of psychiatric disorders, it will be important to determine the extent to which these phenomena are linked. Further examination of the AVP system as a target for clinical intervention is particularly timely because of the advent of AVP-active drugs that can be administered orally $(154,155)$.

\section{AUTHOR CONTRIBUTIONS}

JIT, CFF, and HEA all wrote and revised this manuscript.

\section{ACKNOWLEDGMENTS}

The authors would like to thank Jason Snape for the production of Figure 1.

\section{FUNDING}

This work is supported by R01MH11978526 and R21MH109302 to HEA.

4. Mattson MP. Neurobiology of Aggression. Totowa, New Jersey: Humana Press (2003).

5. Blanchard RJ, Wall PM, Blanchard DC. Problems in the study of rodent aggression. Horm Behav (2003) 44(3):161-70. doi:10.1016/S0018-506X (03)00127-2

6. Ferris CF, DeVries GJ. Ethological models for examining the neurobiology of aggressive and affiliative behaviors. In: Stoff DM, Breiling J, Maser JD, editors. Handbook of Antisocial Behavior. New York: John Wiley and Sons (1997). p. 255-68. 
7. Lonstein JS, Gammie SC. Sensory, hormonal, and neural control of maternal aggression in laboratory rodents. Neurosci Biobehav Rev (2002) 26(8):869-88. doi:10.1016/S0149-7634(02)00087-8

8. Bosch OJ, Neumann ID. Both oxytocin and vasopressin are mediators of maternal care and aggression in rodents: from central release to sites of action. Horm Behav (2012) 61(3):293-303. doi:10.1016/j.yhbeh.2011.11.002

9. Bosch OJ. Maternal aggression in rodents: brain oxytocin and vasopressin mediate pup defence. Philos Trans R Soc Lond B Biol Sci (2013) 368(1631):20130085. doi:10.1098/rstb.2013.0085

10. Birnbaumer M. Vasopressin receptors. Trends Endocrinol Metab (2000) 11(10):406-10. doi:10.1016/S1043-2760(00)00304-0

11. Mahoney PD, Koh ET, Irvin RW, Ferris CF. Computer-aided mapping of vasopressin neurons in the hypothalamus of the male golden hamster: evidence of magnocellular neurons that do not project to the neurohypophysis. J Neuroendocrinol (1990) 2(2):113-22. doi:10.1111/j.1365-2826.1990. tb00840.x

12. Ferris CF, Pilapil CG, Hayden-Hixson D, Wiley RG, Koh ET. Functionally and anatomically distinct populations of vasopressinergic magnocellular neurons in the female golden hamster. J Neuroendocrinol (1992) 4(2): 193-205. doi:10.1111/j.1365-2826.1992.tb00159.x

13. Delville Y, De Vries GJ, Ferris CF. Neural connections of the anterior hypothalamus and agonistic behavior in golden hamster. Brain Behav Evol (2000) 55(2):53-76. doi:10.1159/000006642

14. Bester-Meredith JK, Marler CA. Vasopressin and aggression in cross-fostered California mice (Peromyscus californicus) and white-footed mice (Peromyscus leucopus). Horm Behav (2001) 40(1):51-64. doi:10.1006/hbeh.2001.1666

15. D'Eath RB, Ormandy E, Lawrence AB, Sumner BE, Meddle SL. Residentintruder trait aggression is associated with differences in lysine vasopressin and serotonin receptor 1A (5-HT1A) mRNA expression in the brain of pre-pubertal female domestic pigs (Sus scrofa). J Neuroendocrinol (2005) 17(10):679-86. doi:10.1111/j.1365-2826.2005.01359.x

16. Albers HE. Species, sex and individual differences in the vasotocin/vasopressin system: relationship to neurochemical signaling in the social behavior neural network. Front Neuroendocrinol (2015) 36:49-71. doi:10.1016/j. yfrne.2014.07.001

17. DiBenedictis BT, Nussbaum ER, Cheung HK, Veenema AH. Quantitative mapping reveals age and sex differences in vasopressin, but not oxytocin, immunoreactivity in the rat social behavior neural network. J Comp Neurol (2017) 525(11):2549-70. doi:10.1002/cne.24216

18. Buijs RM. Vasopressin and oxytocin - their role in neurotransmission. Pharmacol Ther (1983) 22:127-41. doi:10.1016/0163-7258(83)90056-6

19. Sofroniew MV. Morphology of vasopressin and oxytocin neurones and their central and vascular projections. Prog Brain Res (1983) 60:101-14. doi:10.1016/S0079-6123(08)64378-2

20. De Vries GJ, Buijs RM. The origin of the vasopressinergic and oxytocinergic innervation of the rat brain with special reference to the lateral septum. Brain Res (1983) 273(2):307-17. doi:10.1016/0006-8993(83)90855-7

21. Dubois-Dauphin M, Pevet P, Tribollet E, Dreifuss JJ. Vasopressin in the brain of the golden hamster: the distribution of vasopressin binding sites and of immunoreactivity to the vasopressin-related glycopeptide. JComp Neurol (1990) 300:535-48. doi:10.1002/cne.903000408

22. De Vries GJ, Panzica GC. Sexual differentiation of central vasopressin and vasotocin systems in vertebrates: different mechanisms, similar endpoints. Neuroscience (2006) 138(3):947-55. doi:10.1016/j.neuroscience.2005.07.050

23. Rood BD, De Vries GJ. Vasopressin innervation of the mouse (Mus musculus) brain and spinal cord. J Comp Neurol (2011) 519(12):2434-74. doi:10.1002/ cne. 22635

24. Song ZA, Albers HE. Cross-talk among oxytocin and arginine-vasopressin receptors: relevance for basic and clinical studies of the brain and periphery. Front Neuroendocrinol (Forthcoming 2017). doi:10.1016/j.yfrne.2017.10.004

25. Ferris CF, Potegal M. Vasopressin receptor blockade in the anterior hypothalamus suppresses aggression in hamsters. Physiol Behav (1988) 44(2):235-9. doi:10.1016/0031-9384(88)90144-8

26. Potegal $M$, Ferris $C F$. Intraspecific aggression in male hamsters is inhibited by intrahypothalamic vasopressin-receptor antagonist. Aggressive Behav (1989) 15:311-20. doi:10.1002/ab.2480150406

27. Ferris CF, Melloni RH Jr, Koppel G, Perry KW, Fuller RW, Delville Y. Vasopressin/serotonin interactions in the anterior hypothalamus control aggressive behavior in golden hamsters. J Neurosci (1997) 17(11):4331-40.
28. Caldwell HK, Albers HE. Effect of photoperiod on vasopressin-induced aggression in Syrian hamsters. Horm Behav (2004) 46(4):444-9. doi:10.1016/j. yhbeh.2004.04.006

29. Gobrogge KL, Liu Y, Young LJ, Wang Z. Anterior hypothalamic vasopressin regulates pair-bonding and drug-induced aggression in a monogamous rodent. Proc Natl Acad Sci U S A (2009) 106(45):19144-9. doi:10.1073/pnas. 0908620106

30. Morrison TR, Melloni RH Jr. The role of serotonin, vasopressin, and serotonin/vasopressin interactions in aggressive behavior. Curr Top Behav Neurosci (2014) 17:189-228. doi:10.1007/7854_2014_283

31. Huhman KL, Jasnow AM, Janicki MM, Mickley NC, Albers HE. Vasopressin (AVP) dose-dependently increases flank marking but not aggressive behavior in Syrian hamsters. Neurosci Abs (1998) 24:1927.

32. Albers HE, Dean A, Karom MC, Smith D, Huhman KL. Role of V1a vasopressin receptors in the control of aggression in Syrian hamsters. Brain Res (2006) 1073-1074:425-30. doi:10.1016/j.brainres.2005.12.081

33. Ross APS, Larkin T, Song EZ, Albers HE. Sex differences and social experience in the regulation of arginine-vasopressin (AVP) V1a and serotonin (5-HT) 1a receptors and aggression in syrian hamsters. Meeting of the Society for Behavioral Neuroendocrinology (2015).

34. Winslow JT, Hastings N, Carter CS, Harbaugh CR, Insel TR. A role for central vasopressin in pair bonding in monogamous prairie voles. Nature (1993) 365(6446):545-8. doi:10.1038/365545a0

35. Melloni RH Jr, Ricci LA. Adolescent exposure to anabolic/androgenic steroids and the neurobiology of offensive aggression: a hypothalamic neural model based on findings in pubertal Syrian hamsters. Horm Behav (2010) 58(1):177-91. doi:10.1016/j.yhbeh.2009.11.002

36. Harrison RJ, Connor DF, Nowak C, Nash K, Melloni RH Jr. Chronic anabolicandrogenic steriod treatment during adolescence increases anterior hypothalamic vasopressin and aggression in intact hamsters. Psychoneuroendocrinology (2000) 25:317-38. doi:10.1016/S0306-4530(99)00057-8

37. DeLeon KR, Grimes JM, Melloni RH Jr. Repeated anabolic-androgenic steroid treatment during adolescence increases vasopressin $\mathrm{V}(1 \mathrm{~A})$ receptor binding in Syrian hamsters: correlation with offensive aggression. Horm Behav (2002) 42(2):182-91. doi:10.1006/hbeh.2002.1802

38. Grimes JM, Ricci LA, Melloni RH Jr. Alterations in anterior hypothalamic vasopressin, but not serotonin, correlate with the temporal onset of aggressive behavior during adolescent anabolic-androgenic steroid exposure in hamsters (Mesocricetus auratus). Behav Neurosci (2007) 121(5):941-8. doi:10.1037/0735-7044.121.5.941

39. Grimes JM, Ricci LA, Melloni RH Jr. Plasticity in anterior hypothalamic vasopressin correlates with aggression during anabolic-androgenic steroid withdrawal in hamsters. Behav Neurosci (2006) 120(1):115-24. doi:10.1037/0735-7044.120.1.115

40. Harrison RJ, Connor DF, Nowak C, Melloni RH Jr. Chronic low-dose cocaine treatment during adolescence facilitates aggression in hamsters. Physiol Behav (2000) 69(4-5):555-62. doi:10.1016/S0031-9384(00)00220-1

41. Jackson D, Burns R, Trksak G, Simeone B, DeLeon KR, Connor DF, et al. Anterior hypothalamic vasopressin modulates the aggression-stimulating effects of adolescent cocaine exposure in Syrian hamsters. Neuroscience (2005) 133(3):635-46. doi:10.1016/j.neuroscience.2005.02.047

42. Delville Y, Mansour KM, Ferris CF. Serotonin blocks vasopressinfacilitated offensive aggression: interactions within the ventrolateral hypothalamus of golden hamsters. Physiol Behav (1996) 59(4-5):813-6. doi:10.1016/ 0031-9384(95)02166-3

43. Delville Y, Ferris CF. Sexual differences in vasopressin receptor-binding within the ventrolateral hypothalamus in golden-hamsters. Brain Res (1995) 681(1-2):91-6. doi:10.1016/0006-8993(95)00291-W

44. Johnson AE, Barberis C, Albers HE. Castration reduces vasopressin receptor binding in the hamster hypothalamus. Brain Res (1995) 674(1):153-8. doi:10.1016/0006-8993(95)00010-N

45. Young LJ, Wang Z, Cooper TT, Albers HE. Vasopressin (V1a) receptor binding, mRNA expression and transcriptional regulation by androgen in the Syrian hamster brain. J Neuroendocrinol (2000) 12(12):1179-85. doi:10.1046/j.1365-2826.2000.00573.x

46. Steinman MQ, Laredo SA, Lopez EM, Manning CE, Hao RC, Doig IE, et al. Hypothalamic vasopressin systems are more sensitive to the long term effects of social defeat in males versus females. Psychoneuroendocrinology (2015) 51:122-34. doi:10.1016/j.psyneuen.2014.09.009 
47. Compaan JC, Buijs RM, Pool CW, De Ruiter AJ, Koolhaas JM. Differential lateral septal vasopressin innervation in aggressive and nonaggressive male mice. Brain Res Bull (1993) 30(1-2):1-6. doi:10.1016/0361-9230(93)90032-7

48. Everts HG, de Ruiter AJ, Koolhaas JM. Differential lateral septal vasopressin in wild-type rats: correlation with aggression. Horm Behav (1997) 31(2):136-44. doi:10.1006/hbeh.1997.1375

49. Beiderbeck DI, Neumann ID, Veenema AH. Differences in intermale aggression are accompanied by opposite vasopressin release patterns within the septum in rats bred for low and high anxiety. Eur J Neurosci (2007) 26(12):3597-605. doi:10.1111/j.1460-9568.2007.05974.x

50. Wersinger SR, Caldwell HK, Martinez L, Gold P, Hu SB, Young WS III. Vasopressin 1a receptor knockout mice have a subtle olfactory deficit but normal aggression. Genes Brain Behav (2007) 6(6):540-51. doi:10.1111/ j.1601-183X.2006.00281.x

51. Wersinger SR, Ginns EI, O'Carroll AM, Lolait SJ, Young WS III. Vasopressin $\mathrm{V} 1 \mathrm{~b}$ receptor knockout reduces aggressive behavior in male mice. Mol Psychiatry (2002) 7(9):975-84. doi:10.1038/sj.mp.4001195

52. Stevenson EL, Caldwell HK. The vasopressin $1 \mathrm{~b}$ receptor and the neural regulation of social behavior. Horm Behav (2012) 61(3):277-82. doi:10.1016/j. yhbeh.2011.11.009

53. Wersinger SR, Kelliher KR, Zufall F, Lolait SJ, O'Carroll AM, Young WS III. Social motivation is reduced in vasopressin $1 \mathrm{~b}$ receptor null mice despite normal performance in an olfactory discrimination task. Horm Behav (2004) 46(5):638-45. doi:10.1016/j.yhbeh.2004.07.004

54. Caldwell HK, Wersinger SR, Young WS III. The role of the vasopressin $1 \mathrm{~b}$ receptor in aggression and other social behaviours. Prog Brain Res (2008) 170:65-72. doi:10.1016/s0079-6123(08)00406-8

55. Wersinger SR, Caldwell HK, Christiansen M, Young WS III. Disruption of the vasopressin $1 \mathrm{~b}$ receptor gene impairs the attack component of aggressive behavior in mice. Genes Brain Behav (2007) 6(7):653-60. doi:10.1111/j.1601-183X.2006.00294.x

56. Blanchard RJ, Griebel G, Farrokhi C, Markham C, Yang M, Blanchard DC. AVP V1b selective antagonist SSR149415 blocks aggressive behaviors in hamsters. Pharmacol Biochem Behav (2005) 80(1):189-94. doi:10.1016/j. pbb.2004.10.024

57. Pagani JH, Zhao M, Cui Z, Avram SK, Caruana DA, Dudek SM, et al. Role of the vasopressin $1 \mathrm{~b}$ receptor in rodent aggressive behavior and synaptic plasticity in hippocampal area CA2. Mol Psychiatry (2015) 20(4):490-9. doi:10.1038/mp.2014.47

58. Darwin C. The Descent of Man, and Selection in Relation to Sex. London: J. Murray (1871).

59. Huchard E, Cowlishaw G. Female-female aggression around mating: an extra cost of sociality in a multimale primate society. Behav Ecol (2011) 22(5):1003-11. doi:10.1093/beheco/arr083

60. Rosvall KA. Intrasexual competition in females: evidence for sexual selection? Behav Ecol (2011) 22:1131-40. doi:10.1093/beheco/arr106

61. Stockley P, Bro-Jorgensen J. Female competition and its evolutionary consequences in mammals. Biol Rev Camb Philos Soc (2011) 86(2):341-66. doi:10.1111/j.1469-185X.2010.00149.x

62. Bangasser DA, Valentino RJ. Sex differences in stress-related psychiatric disorders: neurobiological perspectives. Front Neuroendocrinol (2014) 35(3):303-19. doi:10.1016/j.yfrne.2014.03.008

63. Blanchard RJ, Flannelly KJ, Blanchard DC. Life-span studies of dominance and aggression in established colonies of laboratory rats. Physiol Behav (1988) 43(1):1-7. doi:10.1016/0031-9384(88)90089-3

64. Palanza P, Parmigiani S. How does sex matter? Behavior, stress and animal models of neurobehavioral disorders. Neurosci Biobehav Rev (2017) 76 (Pt A):134-43. doi:10.1016/j.neubiorev.2017.01.037

65. Payne AP, Swanson HH. Agonistic behaviour between pairs of hamsters of the same and opposite sex in a neutral observation area. Behaviour (1970) 36(4):260-9. doi:10.1163/156853970X00402

66. Huck UW, Lisk RD, McKay MV. Social dominance and reproductive success in pregnant and lactating golden hamsters (Mesocricetus auratus) under seminatural conditions. Physiol Behav (1988) 44(3):313-9. doi:10.1016/ 0031-9384(88)90031-5

67. Drickamer LC, Vandenbergh JG. Predictors of social dominance in the adult female Golden hamster. Anim Behav (1973) 21:564-70. doi:10.1016/ S0003-3472(73)80017-X
68. Gutzler SJ, Karom M, Erwin WD, Albers HE. Arginine-vasopressin and the regulation of aggression in female Syrian hamsters (Mesocricetus auratus). Eur J Neurosci (2010) 31(9):1655-63. doi:10.1111/j.1460-9568.2010.07190.x

69. Terranova JI, Song Z, Larkin TE II, Hardcastle N, Norvelle A, Riaz A, et al. Serotonin and arginine-vasopressin mediate sex differences in the regulation of dominance and aggression by the social brain. Proc Natl Acad Sci U S A (2016) 113(46):13233-8. doi:10.1073/pnas.1610446113

70. Stribley JM, Carter CS. Developmental exposure to vasopressin increases aggression in adult prairie voles. Proc Natl Acad Sci U S A (1999) 96(22):12601-4. doi:10.1073/pnas.96.22.12601

71. Carter CS, Boone EM, Pournajafi-Nazarloo H, Bales KL. Consequences of early experiences and exposure to oxytocin and vasopressin are sexually dimorphic. Dev Neurosci (2009) 31(4):332-41. doi:10.1159/000216544

72. Wilson VA, Weiss A, Humle T, Morimura N, Udono T, Idani G, et al. Chimpanzee personality and the arginine vasopressin receptor $1 \mathrm{~A}$ genotype. Behav Genet (2017) 47(2):215-26. doi:10.1007/s10519-016-9822-2

73. Coccaro EF, Kavoussi RJ, Hauger RL, Cooper TB, Ferris CF. Cerebrospinal fluid vasopressin levels: correlates with aggression and serotonin function in personality-disordered subjects. Arch Gen Psychiatry (1998) 55(8):708-14. doi:10.1001/archpsyc.55.8.708

74. Thompson RR, George K, Walton JC, Orr SP, Benson J. Sex-specific influences of vasopressin on human social communication. Proc Natl Acad Sci U S A (2006) 103(20):7889-94. doi:10.1073/pnas.0600406103

75. Ferris CF. Neuroplasticity and aggression. In: Nelson RJ, editor. Biology of Aggression. Oxford: Oxford University Press (2005). p. 163-78.

76. Morin LP, Meyer-Bernstein EL. The ascending serotonergic system in the hamster: comparison with projections of the dorsal median raphe nuclei. Neuroscience (1999) 91(1):81-105. doi:10.1016/S0306-4522(98)00585-5

77. Ferris CF, Stolberg T, Delville Y. Serotonin regulation of aggressive behavior in male golden hamsters (Mesocricetus auratus). Behav Neurosci (1999) 113(4):804-15. doi:10.1037/0735-7044.113.4.804

78. Ferrari PF, Palanza P, Parmigiani S, de Almeida RM, Miczek KA. Serotonin and aggressive behavior in rodents and nonhuman primates: predispositions and plasticity. Eur J Pharmacol (2005) 526(1-3):259-73. doi:10.1016/j. ejphar.2005.10.002

79. Taravosh-Lahn K, Bastida C, Delville Y. Differential responsiveness to fluoxetine during puberty. Behav Neurosci (2006) 120(5):1084-92. doi:10.1037/0735-7044.120.5.1084

80. Ricci LA, Melloni RH Jr. Repeated fluoxetine administration during adolescence stimulates aggressive behavior and alters serotonin and vasopressin neural development in hamsters. Behav Neurosci (2012) 126(5):640-53. doi:10.1037/a0029761

81. Joppa MA, Rowe RK, Meisel RL. Effects of serotonin 1A or 1B receptor agonists on social aggression in male and female Syrian hamsters. Pharmacol Biochem Behav (1997) 58(2):349-53. doi:10.1016/S0091-3057(97)00277-3

82. Villalba C, Boyle PA, Caliguri EJ, De Vries GJ. Effects of the selective serotonin reuptake inhibitor fluoxetine on social behaviors in male and female prairie voles (Microtus ochrogaster). Horm Behav (1997) 32(3):184-91. doi:10.1006/ hbeh.1997.1420

83. Caldwell HK, Albers HE. Oxytocin, vasopressin, and the motivational forces that drive social behaviors. Curr Top Behav Neurosci (2016) 27:51-103. doi:10.1007/7854_2015_390

84. Caldwell HK. Oxytocin and vasopressin: powerful regulators of social behavior. Neuroscientist (2017). doi:10.1177/1073858417708284

85. Harmon AC, Huhman KL, Moore TO, Albers HE. Oxytocin inhibits aggression in female Syrian hamsters. J Neuroendocrinol (2002) 14(12):963-9. doi:10.1046/j.1365-2826.2002.00863.x

86. Winslow JT, Hearn EF, Ferguson J, Young LJ, Matzuk MM, Insel TR. Infant vocalization, adult aggression, and fear behavior of an oxytocin null mutant mouse. Horm Behav (2000) 37(2):145-55. doi:10.1006/hbeh.1999.1566

87. Ragnauth AK, Devidze N, Moy V, Finley K, Goodwillie A, Kow LM, et al. Female oxytocin gene-knockout mice, in a semi-natural environment, display exaggerated aggressive behavior. Genes Brain Behav (2005) 4(4):229-39. doi:10.1111/j.1601-183X.2005.00118.x

88. Takayanagi Y, Yoshida M, Bielsky IF, Ross HE, Kawamata M, Onaka T, et al. Pervasive social deficits, but normal parturition, in oxytocin receptordeficient mice. Proc Natl Acad Sci U S A (2005) 102(44):16096-101. doi:10.1073/pnas.0505312102 
89. Schorscher-Petcu A, Sotocinal S, Ciura S, Dupre A, Ritchie J, Sorge RE, et al. Oxytocin-induced analgesia and scratching are mediated by the vasopressin-1A receptor in the mouse. J Neurosci (2010) 30(24):8274-84. doi:10.1523/JNEUROSCI.1594-10.2010

90. Song Z, McCann KE, McNeill JK, Larkin TE II, Huhman KL, Albers HE. Oxytocin induces social communication by activating arginine-vasopressin V1a receptors and not oxytocin receptors. Psychoneuroendocrinology (2014) 50:14-9. doi:10.1016/j.psyneuen.2014.08.005

91. Song Z, Borland JM, Larkin TE, O'Malley M, Albers HE. Activation of oxytocin receptors, but not arginine-vasopressin V1a receptors, in the ventral tegmental area of male Syrian hamsters is essential for the reward-like properties of social interactions. Psychoneuroendocrinology (2016) 74:164-72. doi:10.1016/j.psyneuen.2016.09.001

92. Song Z, Larkin TE, Malley MO, Albers HE. Oxytocin (OT) and argininevasopressin (AVP) act on OT receptors and not AVP V1a receptors to enhance social recognition in adult Syrian hamsters (Mesocricetus auratus). Horm Behav (2016) 81:20-7. doi:10.1016/j.yhbeh.2016.02.004

93. Fischer SG, Ricci LA, Melloni RH Jr. Repeated anabolic/androgenic steroid exposure during adolescence alters phosphate-activated glutaminase and glutamate receptor 1 (GluR1) subunit immunoreactivity in Hamster brain: correlation with offensive aggression. Behav Brain Res (2007) 180(1):77-85. doi:10.1016/j.bbr.2007.02.025

94. Carrillo M, Ricci LA, Melloni RH. Glutamate and the aggression neural circuit in adolescent anabolic steroid-treated Syrian hamsters (Mesocricetus auratus). Behav Neurosci (2011) 125(5):753-63. doi:10.1037/a0025127

95. Syed N, Martens CA, Hsu WH. Arginine vasopressin increases glutamate release and intracellular $\mathrm{Ca} 2+$ concentration in hippocampal and cortical astrocytes through two distinct receptors. J Neurochem (2007) 103(1):229-37. doi:10.1111/j.1471-4159.2007.04737.x

96. Bernstein IS, Gordon TP, Rose RM. Aggression and social controls in rhesus monkey (Macaca mulatta) groups revealed in group formation studies. Folia Primatol (1974) 21(2):81-107. doi:10.1159/000155607

97. Fernald RD. Communication about social status. Curr Opin Neurobiol (2014) 28:1-4. doi:10.1016/j.conb.2014.04.004

98. Ferris CF, Axelson JF, Shinto LH, Albers HE. Scent marking and the maintenance of dominant/subordinate status in male golden hamsters. Physiol Behav (1987) 40(5):661-4. doi:10.1016/0031-9384(87)90114-4

99. Meisel RL, Joppa MA. Conditioned place preference in female hamsters following aggressive or sexual encounters. Physiol Behav (1994) 56(5):1115-8. doi:10.1016/0031-9384(94)90352-2

100. Martinez M, Guillen-Salazar F, Salvador A, Simon VM. Successful intermale aggression and conditioned place preference in mice. Physiol Behav (1995) 58(2):323-8. doi:10.1016/0031-9384(95)00061-M

101. Huhman KL, Moore TO, Ferris CF, Mougey EH, Meyerhoff JL. Acute and repeated exposure to social conflict in male golden hamsters: increases in plasma POMC-peptides and cortisol and decreases in plasma testosterone. Horm Behav (1991) 25(2):206-16. doi:10.1016/0018-506X(91)90051-I

102. Blanchard DC, Sakai RR, McEwen B, Weiss SM, Blanchard RJ. Subordination stress: behavioral, brain, and neuroendocrine correlates. Behav Brain Res (1993) 58(1-2):113-21. doi:10.1016/0166-4328(93)90096-9

103. Michopoulos V, Reding KM, Wilson ME, Toufexis D. Social subordination impairs hypothalamic-pituitary-adrenal function in female rhesus monkeys. Horm Behav (2012) 62(4):389-99. doi:10.1016/j.yhbeh.2012.07.014

104. Bernstein IS. Dominance, aggression and reproduction in primate societies. J Theor Biol (1976) 60(2):459-72. doi:10.1016/0022-5193(76)90072-2

105. Huhman KL. Social conflict models: can they inform us about human psychopathology? Horm Behav (2006) 50(4):640-6. doi:10.1016/j. yhbeh.2006.06.022

106. Michopoulos V, Higgins M, Toufexis D, Wilson ME. Social subordination produces distinct stress-related phenotypes in female rhesus monkeys. Psychoneuroendocrinology (2012) 37(7):1071-85. doi:10.1016/j. psyneuen.2011.12.004

107. Russo SJ, Murrough JW, Han MH, Charney DS, Nestler EJ. Neurobiology of resilience. Nat Neurosci (2012) 15(11):1475-84. doi:10.1038/nn.3234

108. Berton O, McClung CA, Dileone RJ, Krishnan V, Renthal W, Russo SJ, et al. Essential role of BDNF in the mesolimbic dopamine pathway in social defeat stress. Science (2006) 311(5762):864-8. doi:10.1126/science.1120972

109. Yan HC, Cao X, Das M, Zhu XH, Gao TM. Behavioral animal models of depression. Neurosci Bull (2010) 26(4):327-37. doi:10.1007/s12264-010-0323-7
110. Chaouloff F. Social stress models in depression research: what do they tell us? Cell Tissue Res (2013) 354(1):179-90. doi:10.1007/s00441-013-1606-x

111. Hattori T, Wilczynski W. Comparison of arginine vasotocin immunoreactivity differences in dominant and subordinate green anole lizards. Physiol Behav (2009) 96(1):104-7. doi:10.1016/j.physbeh.2008.09.010

112. Kabelik D, Klatt JD, Kingsbury MA, Goodson JL. Endogenous vasotocin exerts context-dependent behavioral effects in a semi-naturalistic colony environment. Horm Behav (2009) 56(1):101-7. doi:10.1016/j.yhbeh.2009.03.017

113. Boyd SK. Vasotocin modulation of social behaviors in amphibians. In: Choleris E, Pfaff DW, Kavaliers M, editors. Oxytocin, Vasopressin and Related Peptides in the Regulation of Behavior. Cambridge, UK: Cambridge University Press (2013). p. 97-109.

114. Thompson RW, Walton JC. Social regulatory functions of vasotocin and isotocin in fish. In: Choleris E, Pfaff DW, Kavaliers M, editors. Oxytocin, Vasopressin and Related Peptides in the Regulation of Behavior. Cambridge: Cambridge University Press (2013). p. 75-96.

115. Almeida O, Oliveira RF. Social status and arginine vasotocin neuronal phenotypes in a cichlid fish. Brain Behav Evol (2015) 85(3):203-13. doi:10.1159/000381251

116. Ferris CF, Axelson JF, Martin AM, Roberge LF. Vasopressin immunoreactivity in the anterior hypothalamus is altered during the establishment of dominant/subordinate relationships between hamsters. Neuroscience (1989) 29(3):675-83. doi:10.1016/0306-4522(89)90140-1

117. Cooper MA, Karom M, Huhman KL, Albers HE. Repeated agonistic encounters in hamsters modulate AVP V1a receptor binding. Horm Behav (2005) 48(5):545-51. doi:10.1016/j.yhbeh.2005.04.012

118. Caldwell HK, Dike OE, Stevenson EL, Storck K, Young WS III. Social dominance in male vasopressin $1 \mathrm{~b}$ receptor knockout mice. Horm Behav (2010) 58(2):257-63. doi:10.1016/j.yhbeh.2010.03.008

119. Qiao X, Yan Y, Wu R, Tai F, Hao P, Cao Y, et al. Sociality and oxytocin and vasopressin in the brain of male and female dominant and subordinate mandarin voles. J Comp Physiol A Neuroethol Sens Neural Behav Physiol (2014) 200(2):149-59. doi:10.1007/s00359-013-0870-2

120. Erhardt A, Muller MB, Rodel A, Welt T, Ohl F, Holsboer F, et al. Consequences of chronic social stress on behaviour and vasopressin gene expression in the PVN of DBA/2OlaHsd mice - influence of treatment with the CRHR1antagonist R121919/NBI 30775. J Psychopharmacol (2009) 23(1):31-9. doi:10.1177/0269881108089813

121. Delville Y, Melloni RH Jr, Ferris CF. Behavioral and neurobiological consequences of social subjugation during puberty in golden hamsters. J Neurosci (1998) 18(7):2667-72.

122. Leshner AI, Roche KE. Comparison of the effects of ACTH and lysine vasopressin on avoidance-of-attack in mice. Physiol Behav (1977) 18(5):879-83. doi:10.1016/0031-9384(77)90197-4

123. Siegfried B, Frischknecht H-R, Waser PG. Vasopressin impairs or enhances retention of learned submissive behavior in mice depending on the time of application. Behav Brain Res (1984) 11(3):259-69. doi:10.1016/0166-4328(84)90218-3

124. Roche KE, Leshner AI. ACTH and vasopressin treatments immediately after a defeat increase future submissiveness in male mice. Science (1979) 204(4399):1343-4. doi:10.1126/science.221973

125. Barberis C, Tribollet E. Vasopressin and oxytocin receptors in the central nervous system. Crit Rev Neurobiol (1996) 10(1):119-54. doi:10.1615/ CritRevNeurobiol.v10.i1.60

126. Johnston RE. Scent marking by male golden hamsters (Mesocricetus auratus) I. Effects of odors and social encounters. Z Tierpsychol (1975) 37(1):75-98. doi:10.1111/j.1439-0310.1975.tb01128.x

127. Huck UW, Lisk RD, Gore AC. Scent marking and mate choice in the golden hamster. Physiol Behav (1985) 35(3):389-93. doi:10.1016/0031-9384(85) 90314-2

128. Irvin RW, Szot P, Dorsa DM, Potegal M, Ferris CF. Vasopressin in the septal area of the golden hamster controls scent marking and grooming. Physiol Behav (1990) 48(5):693-9. doi:10.1016/0031-9384(90)90213-N

129. Hennessey AC, Whitman DC, Albers HE. Microinjection of argininevasopressin into the periaqueductal gray stimulates flank marking in Syrian-hamsters (Mesocricetus auratus). Brain Res (1992) 569(1):136-40. doi:10.1016/0006-8993(92)90379-N

130. Bamshad M, Albers HE. Neural circuitry controlling vasopressinstimulated scent marking in Syrian hamsters (Mesocricetus auratus). J Comp 
Neurol (1996) 369(2):252-63. doi:10.1002/(SICI)1096-9861(19960527)369: $2<252::$ AID-CNE6 $>3.0 . \mathrm{CO} ; 2-2$

131. Albers HE. The regulation of social recognition, social communication and aggression: vasopressin in the social behavior neural network. Horm Behav (2012) 61(3):283-92. doi:10.1016/j.yhbeh.2011.10.007

132. Ferris CF, Melloni RH, Albers HE. Role of vasopressin in flank marking and aggression. In: Choleris E, Pfaff DW, Kavaliers M, editors. Oxytocin, Vasopressin and Related Peptides in the Regulation of Behavior. Cambridge, UK: Cambridge University Press (2013):p.213-31.

133. Ferris CF, Albers HE, Wesolowski SM, Goldman BD, Luman SE. Vasopressin injected into the hypothalamus triggers a stereotypic behavior in golden hamsters. Science (1984) 224(4648):521-3. doi:10.1126/science.6538700

134. Ferris CF, Pollock J, Albers HE, Leeman SE. Inhibition of flank-marking behavior in golden hamsters by microinjection of a vasopressin antagonist into the hypothalamus. Neurosci Lett (1985) 55(2):239-43. doi:10.1016/ 0304-3940(85)90027-8

135. Albers HE, Pollock J, Simmons WH, Ferris CF. A V1-like receptor mediates vasopressin-induced flank marking behavior in hamster hypothalamus. J Neurosci (1986) 6(7):2085-9.

136. Ferris CF, Singer EA, Meenan DM, Albers HE. Inhibition of vasopressinstimulated flank marking behavior by V1-receptor antagonists. Eur J Pharmacol (1988) 154(2):153-9. doi:10.1016/0014-2999(88)90092-1

137. Ferris CF, Meenan DM, Axelson JF, Albers HE. A vasopressin antagonist can reverse dominant/subordinate behavior in hamsters. Physiol Behav (1986) 38(1):135-8. doi:10.1016/0031-9384(86)90143-5

138. Hennessey AC, Huhman KL, Albers HE. Vasopressin and sex differences in hamster flank marking. Physiol Behav (1994) 55(5):905-11. doi:10.1016/0031-9384(94)90078-7

139. Caldwell HK, Albers HE. Short-photoperiod exposure reduces vasopressin (V1a) receptor binding but not arginine-vasopressin-induced flank marking in male Syrian hamsters. J Neuroendocrinol (2003) 15(10):971-7. doi:10.1046/j.1365-2826.2003.01086.x

140. Whitman DC, Hennessey AC, Albers HE. Norepinephrine inhibits vasopressin-stimulated flank marking in the Syrian-hamster by acting within the medial preoptic-anterior hypothalamus. J Neuroendocrinol (1992) 4(5):541-6. doi:10.1111/j.1365-2826.1992.tb00202.x

141. Ferris CF, Delville Y, Bonigut S, Miller MA. Galanin antagonizes vasopressinstimulated flank marking in male golden hamsters. Brain Res (1999) 832 (1-2):1-6. doi:10.1016/S0006-8993(99)01432-8

142. Gutzler SJ, Karom M, Erwin WD, Albers HE. Seasonal regulation of social communication by photoperiod and testosterone: effects of argininevasopressin, serotonin and galanin in the medial preoptic area-anterior hypothalamus. Behav Brain Res (2011) 216(1):214-9. doi:10.1016/j.bbr.2010. 07.042

143. Bamshad M, Cooper TT, Karom M, Albers HE. Glutamate and vasopressin interact to control scent marking in Syrian hamsters (Mesocricetus auratus). Brain Res (1996) 731(1-2):213-6. doi:10.1016/0006-8993(96)00670-1

144. Ferris CF, Delville Y. Vasopressin and serotonin interactions in the control of agonistic behavior. Psychoneuroendocrinology (1994) 19(5-7):593-601. doi:10.1016/0306-4530(94)90043-4

145. Hardcastle NL, Larkin TE, Terranova JI, Norvelle A, Albers HE. Role of arginine-vasopressin (AVP), serotonin, (5-HT) and galanin (GAL) with the anterior hypothalamus (AH) on aggression and social communication in male and female hamsters. Soc Neurosci (2016) 113(46):13233-8.

146. Albers HE, Karom M, Smith D. Serotonin and vasopressin interact in the hypothalamus to control communicative behavior. Neuroreport (2002) 13(7):931-3. doi:10.1097/00001756-200205240-00006

147. Ferris CF, Rasmussen MF, Messenger T, Koppel G. Vasopressin-dependent flank marking in golden hamsters is suppressed by drugs used in the treatment of obsessive-compulsive disorder. BMC Neurosci (2001) 2:10. doi:10.1186/1471-2202-2-10

148. Cooper MA, Grober MS, Nicholas CR, Huhman KL. Aggressive encounters alter the activation of serotonergic neurons and the expression of 5-HT1A mRNA in the hamster dorsal raphe nucleus. Neuroscience (2009) 161(3): 680-90. doi:10.1016/j.neuroscience.2009.03.084

149. Cooper MA, McIntyre KE, Huhman KL. Activation of 5-HT1A autoreceptors in the dorsal raphe nucleus reduces the behavioral consequences of social defeat. Psychoneuroendocrinology (2008) 33(9):1236-47. doi:10.1016/j. psyneuen.2008.06.009

150. Harvey ML, Swallows CL, Cooper MA. A double dissociation in the effects of 5-HT2A and 5-HT2C receptors on the acquisition and expression of conditioned defeat in Syrian hamsters. Behav Neurosci (2012) 126(4):530-7. doi:10.1037/a0029047

151. Koolhaas JM, de Boer SF, Coppens CM, Buwalda B. Neuroendocrinology of coping styles: towards understanding the biology of individual variation. Front Neuroendocrinol (2010) 31(3):307-21. doi:10.1016/j.yfrne. 2010.04.001

152. Cooper MA, Clinard CT, Morrison KE. Neurobiological mechanisms supporting experience-dependent resistance to social stress. Neuroscience (2015) 291:1-14. doi:10.1016/j.neuroscience.2015.01.072

153. Johnson ZV, Young LJ. Oxytocin and vasopressin neural networks: implications for social behavioral diversity and translational neuroscience. Neurosci Biobehav Rev (2017) 76(Pt A):87-98. doi:10.1016/j.neubiorev.2017.01.034

154. Ferris CF, Lu SF, Messenger T, Guillon CD, Heindel N, Miller M, et al. Orally active vasopressin V1a receptor antagonist, SRX251, selectively blocks aggressive behavior. Pharmacol Biochem Behav (2006) 83(2):169-74. doi:10.1016/j.pbb.2006.01.001

155. Umbricht D, Del Valle Rubido M, Hollander E, McCracken JT, Shic F, Scahill L, et al. A single dose, randomized, controlled proof-of-mechanism study of a novel vasopressin 1a receptor antagonist (RG7713) in high-functioning adults with autism spectrum disorder. Neuropsychopharmacology (2017) 42(9):1914-23. doi:10.1038/npp.2016.232

Conflict of Interest Statement: The authors declare that the research was conducted in the absence of any commercial or financial relationships that could be construed as a potential conflict of interest.

Copyright (C) 2017 Terranova, Ferris and Albers. This is an open-access article distributed under the terms of the Creative Commons Attribution License (CC BY). The use, distribution or reproduction in other forums is permitted, provided the original author(s) or licensor are credited and that the original publication in this journal is cited, in accordance with accepted academic practice. No use, distribution or reproduction is permitted which does not comply with these terms. 